\title{
Outcome of Maternal Anaemia on Cord Haemoglobin of the Newborn in Port Harcourt, Nigeria
}

\author{
Justina Omoikhefe Alegbeleye, Dagogo Semenitari Abam, Ngozi Clare Orazulike \\ Department of Obstetrics and Gynaecology, University of Port Harcourt, Port Harcourt, Rivers State, Nigeria \\ Email: drefe_2@yahoo.co.uk
}

How to cite this paper: Alegbeleye, J.O., Abam, D.S. and Orazulike, N.C. (2020) Outcome of Maternal Anaemia on Cord Haemoglobin of the Newborn in Port Harcourt, Nigeria. Journal of Biosciences and Medicines, 8, 142-152.

https://doi.org/10.4236/jbm.2020.85014

Received: April 7, 2020

Accepted: May 12, 2020

Published: May 15, 2020

Copyright ( 2020 by author(s) and Scientific Research Publishing Inc. This work is licensed under the Creative Commons Attribution International License (CC BY 4.0).

http://creativecommons.org/licenses/by/4.0/

\begin{abstract}
Background: Anaemia is a common medical disorder in pregnancy especially in developing countries. Iron deficiency anaemia during pregnancy may be associated with adverse pregnancy outcomes. Objectives: To determine the cord blood haemoglobin and the correlation between maternal haemoglobin concentration and perinatal outcome at the University of Port Harcourt Teaching Hospital. Materials and Methods: This was a prospective cross-sectional study of 155 pregnant women who presented at the labour ward of the department of Obstetrics and Gynaecology from October 1, 2018 to December 31,2018 . Blood sample was collected from the women in labour into ethylenediamine tetra-acetic acid (EDTA) bottles, red blood cell haemoglobin was determined. Umbilical cord blood sample was also collected at delivery and red cell haemoglobin was done. Socio-demographic characteristics, risk factors and perinatal outcome were obtained, entered into a spreadsheet and analyzed using SPSS 22.0. Bivariate logistic regression analysis was performed for multivariate analysis and statistical significance was considered at $\mathrm{p}<0.05$. Results: The mean age of the women was $31.08 \pm 4.39$ years, the mean maternal haemoglobin concentration was $11.54 \pm 1.86 \mathrm{~g} / \mathrm{dl}$ while the mean umbilical cord haemoglobin concentration was $12.92 \pm 1.92 \mathrm{~g} / \mathrm{dl}$. Majority $(86.45 \%)$ of the women were compliant with the prescribed haematinics. Moderate anaemia was observed in $17.42 \%$ of the women, followed by mild anaemia $(15.48 \%)$ and severe anaemia (1.29\%) respectively. Maternal complications were observed in $24.5 \%$ of women. There was a significant association between maternal haemoglobin concentration and cord blood haemoglobin concentration $(\mathrm{p}=0.001)$. However, the study did not show an association between parity, mode of delivery, birth weight, Apgar scores, gestational age and maternal haemoglobin concentration $(p>0.05)$. Conclusion: The mean
\end{abstract}


Haemoglobin in our newborns was less than previously reported values. Cord blood haemoglobin decreases significantly with decreasing maternal haemoglobin, thus there is a linear relationship between maternal and cord blood haemoglobin.

\section{Keywords}

Maternal Haemoglobin, Cord Blood Haemoglobin, Perinatal Outcome, Nigeria

\section{Introduction}

Anaemia is the commonest medical disorder in pregnancy especially in subSaharan Africa due to poor nutrition and a high prevalence of parasitic infestation. It has a varied prevalence, aetiology and degree of severity in different populations [1].

The World Health Organization defines anaemia in pregnancy as a haemoglobin concentration of less than $11 \mathrm{~g} / \mathrm{dl}$ and a haematocrit of less than 33\% [2]. It is further classified as 10.0 to $10.9 \mathrm{~g} / \mathrm{dl}$ for mild anaemia, 7.0 to $9.9 \mathrm{~g} / \mathrm{dl}$ for moderate anaemia and lower than $7.0 \mathrm{~g} / \mathrm{l}$ for severe anaemia [2]. However, in subSaharan Africa, Lawson and Harrison showed that serious harm to the fetus did not occur until the haemoglobin value was below $10 \mathrm{~g} / \mathrm{dl}$ or packed cell volume of $30 \%$ [3]. Anaemia affects $35 \%$ - 75\% of pregnant women in developing countries including Nigeria and $18 \%$ of women in developed countries [4] [5]. It is commoner in the third trimester than in the first and second trimesters of pregnancy [5]. This high prevalence in developing countries and the factors responsible are diverse and reflect differences in race, geographical area, socioeconomic status, nutritional habit, medical care, season and parasitic infestation [6]. It is one of the major contributors to maternal death in developing countries [7].

Anaemia in pregnancy has been shown to be associated with adverse maternal outcomes such as preterm labour, low birth weight, antepartum haemorrhage, puerperal sepsis, postpartum haemorrhage, perinatal and maternal mortality [7] [8] [9]. Maternal anaemia may contribute to fetal anaemia. The cord blood shows a direct relationship with maternal haemoglobin and mothers who are anaemic are more likely to deliver anaemic babies. The umbilical cord blood at birth shows an increase in haemoglobin $(\mathrm{Hb})$, haematocrit ( $\mathrm{Hct}$ ) and other haematological parameters [10]. These haematological values are affected by gestational age, mode of delivery, race, maternal factors, maternal age, parity, and fetal infections. Hence, the need for pre-conceptional counselling for iron supplementation, early diagnosis and treatment of anaemia in pregnancy.

Though there are many studies on anaemia in pregnancy, relatively few studies have addressed both the maternal and fetal outcome. This study examined the correlation between maternal haematocrit level and fetal outcome in Port Harcourt, Nigeria. 


\section{Materials and Methods}

\subsection{Study Site}

This study was carried out at the Obstetric unit of the University of Port Harcourt Teaching Hospital (UPTH) from October 1, 2018 to December 31, 2018. The UPTH is an 882-bed hospital located at Alakahia in Obio-Akpor local government area of Rivers State, South-South Nigeria. An average of 2500 deliveries are conducted annually. The unit has a total of 40 beds in the postnatal ward, 40 beds in the unbooked ward, 13 beds in the first stage room, and 8 beds in the private/semi-private rooms. There are five units; each unit has five consultant obstetricians, five specialist senior registrars and five registrars with many experienced midwives.

\subsection{Methods}

This was a prospective cross-sectional study conducted at the labour ward of the department of Obstetrics and Gynaecology of the University of Port Harcourt Teaching Hospital from October 1, 2018 to December 31, 2018. All pregnant women that presented in labour were included in the study, after fulfilling the inclusion criteria. At presentation, bio-demographic and clinical data were obtained. The socio-demographic characteristics including maternal age, parity, educational level, booking status, gestational age at booking, haemoglobin genotype, risk factors, mode of delivery and perinatal outcome were obtained from case notes, ward and theatre registers, and entered into a spread sheet. The inclusion criteria were singleton pregnancy, term neonates with birth weight of 2.5 - $4 \mathrm{~kg}$, while the exclusion criteria were pregnant women with severe anaemia, early pregnancy bleeding or antepartum haemorrhage, multiple pregnancy, women with chronic medical illness, eclampsia, gestational diabetes mellitus, human immunodeficiency virus (HIV) infection, hepatitis B surface antigen, hepatitis C antibodies, blood transfusion at least three months prior to enrolment in the study, women with blood dyscrasias and haemoglobinopathies, babies born with pathologic jaundice, haemolytic anaemia, congenital anomalies and women who did not give consent.

Three millilitres of blood sample was collected from the antecubital vein or dorsum of the non-dominant hand by venipuncture. Aseptic techniques were applied. Ethylenediamine tetra-acetic acid (EDTA) bottles were used to collect the blood sample and red cell haemoglobin estimation was determined. After delivery, 3 millilitres of cord blood sample was collected from the umbilical cord of the babies by double clamping and cutting the babies' end of the cord and red cell haemoglobin estimation was also done. All samples were analyzed within 4 hours of delivery using an automated haemato-analyzer.

The data generated was coded and analyzed using SPSS 22.0. Bivariate logistic regression analysis using Odds Rations (OR) was performed for multivariate analysis and statistical significance was considered at $\mathrm{p}<0.05$. Maternal outcome measures were antenatal, intrapartum and postpartum complications, mode of 
delivery and haaemoglobin level. Anaemia was classified as mild $10.0-10.9 \mathrm{~g} / \mathrm{dl}$, moderate $7.0-9.9 \mathrm{~g} / \mathrm{dl}$ and severe $<7.0 \mathrm{~g} / \mathrm{dl}$ [2]. Perinatal outcome measures were gestational age at delivery, birth weight, Apgar scores of the babies at birth, haemoglobin concentration and fetal complications. Gestational age was estimated from the women's last menstrual period or from an early ultrasonography. Low birth weight was defined as birth weight $<2500 \mathrm{gm}$ and preterm as gestational age below 37 completed weeks.

\subsection{Statistical Analysis}

Statistical analysis was done using Statistical Package for Social Sciences (SPSS) version 22 (SPSS Inc. Chicago, Illinois, U.S.A.). Bivariate logistic regression analysis was performed for multivariate analysis and statistical significance was considered at $\mathrm{p}<0.05$. The results are presented as mean, standard deviation, and percentages.

\subsection{Ethical Approval}

All authors hereby declare that the study was approved by the ethical review board of the hospital and have therefore been carried out in accordance with the ethical standards laid down in the 1964 Declaration of Helsinki.

\section{Results}

The study included a total of 155 pregnant women and their newborns ( 85 males and 70 females) and majority $131(84.52 \%)$ of respondants were booked. Of the total participants, 97 (62.58\%) were multigravidae, 52 (33.55\%) were primigravidae while $5(3.87 \%)$ were grand multigravidae. The mean age was $31.08 \pm 4.39$ years with 114 (73.55\%) between the age of 25-34 years. Majority $104(67.10 \%)$ of the women had tertiary education. One hundred and twenty-five were delivered by spontaneous vaginal delivery and 30 by caesarean section. Most of the babies 126 (81.29\%) were of normal birth weights. This is shown in Table 1 and Table 2.

According to the WHO classification of anaemia in pregnant women, moderate anaemia was observed in $17.42 \%$ of the women, followed by mild anaemia (15.48\%) and severe anaemia (1.29\%) respectively. The mean maternal haemoglobin concentration was $11.54 \pm 1.86 \mathrm{~g} / \mathrm{dl}$ while the mean haemoglobin concentration of umbilical cord blood was $12.92 \pm 1.92 \mathrm{~g} / \mathrm{dL}$. Two of the women had severe anaemia with an $\mathrm{Hb}<7 \mathrm{~g} / \mathrm{dl}$. This is shown in Table 3.

Table 4 shows a significant association between maternal haemoglobin concentration and cord blood haemoglobin concentration. However, it did not show any significant association with birth weight, Apgar scores and gestational age at delivery. Bivariate logistic regression analysis showed that maternal factors like parity, booking status, and mode of delivery did not influence the cord blood haemoglobin concentration of the babies. As all pregnant mothers were supplemented with iron and folic acid, iron supplementation was not considered as a confounding factor to umbilical cord haemoglobin. 
Table 1. Socio-demographic characteristics of the women.

\begin{tabular}{|c|c|c|}
\hline Characteristics & Frequency $(n=155)$ & Percentage (\%) \\
\hline \multicolumn{3}{|l|}{ Age } \\
\hline$\leq 24$ & 8 & 5.16 \\
\hline $25-34$ & 114 & 73.55 \\
\hline $35-44$ & 32 & 20.65 \\
\hline $45-54$ & 1 & 0.65 \\
\hline \multicolumn{3}{|l|}{ Marital Status } \\
\hline Married & 144 & 92.90 \\
\hline Single & 10 & 6.45 \\
\hline Widow & 1 & 0.65 \\
\hline \multicolumn{3}{|l|}{ Educational Status } \\
\hline None & 1 & 0.65 \\
\hline Primary & 3 & 1.94 \\
\hline Secondary & 47 & 30.32 \\
\hline Tertiary & 104 & 67.10 \\
\hline \multicolumn{3}{|l|}{ Religion } \\
\hline Christian & 154 & 99.35 \\
\hline Muslim & 1 & 0.65 \\
\hline \multicolumn{3}{|l|}{ Jehovah's Witness } \\
\hline Yes & 2 & 1.29 \\
\hline No & 153 & 98.71 \\
\hline
\end{tabular}

Table 2. Characteristics of the neonates.

\begin{tabular}{ccc}
\hline Characteristics & Frequency $(\mathrm{n}=\mathbf{1 5 5})$ & Percentage (\%) \\
\hline Sex & 70 & 45.16 \\
Male & 85 & 54.84 \\
Female & & \\
Birth Weight $(\mathbf{k g})$ & 19 & 12.26 \\
Underweight $(<2.5)$ & 126 & 81.29 \\
Normal $(2.5-3.9)$ & 10 & 6.45 \\
Macrosomic $(\geq 4)$ & & 74.19 \\
Baby's Cord Blood (g/dL) & 115 & 25.81 \\
Normal $(\geq 12)$ & 40 & \\
Abnormal $(\leq 11.9)$ & & \\
Baby's cord blood (g/dL) & & \\
Mean & &
\end{tabular}


Table 3. Maternal characteristics and mean cord blood haemoglobin.

\begin{tabular}{|c|c|c|}
\hline Characteristics & Frequency $(n=155)$ & Percentage (\%) \\
\hline \multicolumn{3}{|l|}{ Booking status } \\
\hline Booked & 131 & 84.52 \\
\hline Un-booked & 24 & 15.48 \\
\hline \multicolumn{3}{|l|}{ Parity } \\
\hline 1. Para $(0)$ & 52 & 33.55 \\
\hline 2. Para $(1-4)$ & 97 & 62.58 \\
\hline 3. Para (5) & 6 & 3.87 \\
\hline \multicolumn{3}{|l|}{ Gestational Age (weeks) } \\
\hline Preterm $(<37)$ & 20 & 12.90 \\
\hline Term $(37-42)$ & 135 & 87.10 \\
\hline Mean & \multicolumn{2}{|c|}{$38.37 \pm 2.65$} \\
\hline \multicolumn{3}{|l|}{ Mode of Delivery } \\
\hline SVD & 125 & 80.65 \\
\hline $\mathrm{C} / \mathrm{S}$ & 30 & 19.35 \\
\hline \multicolumn{3}{|l|}{ Estimated Blood Loss (ml) } \\
\hline Normal (<500 mls) & 138 & 89.03 \\
\hline Post-Partum Haemorrhage ( $\geq 500 \mathrm{mls}$ ) & 17 & 10.97 \\
\hline Mean & \multicolumn{2}{|c|}{$267.74 \pm 227.90$} \\
\hline \multicolumn{3}{|l|}{ Mothers HB (g/dl) } \\
\hline Normal $(\geq 11)$ & 102 & 65.81 \\
\hline Mild (10.0 - 10.9) & 24 & 15.48 \\
\hline Moderate $(7.0-9.9)$ & 27 & 17.42 \\
\hline Severe $(<7.0)$ & 2 & 1.29 \\
\hline Mean & \multicolumn{2}{|c|}{$11.54 \pm 1.86$} \\
\hline \multicolumn{3}{|l|}{ Blood Transfusion } \\
\hline Yes & 4 & 2.58 \\
\hline No & 151 & 97.42 \\
\hline \multicolumn{3}{|l|}{ Number of Units of blood } \\
\hline 0 & 151 & 97.42 \\
\hline 1 & 1 & 0.65 \\
\hline 2 & 2 & 1.29 \\
\hline 3 & 1 & 0.65 \\
\hline \multicolumn{3}{|l|}{ Cord blood haemoglobin (g/dl) } \\
\hline Normal $(\geq 12)$ & 115 & 74.19 \\
\hline Abnormal ( $\leq 11.9)$ & 40 & 25.81 \\
\hline Mean & $12.92 \pm 1.92$ & \\
\hline
\end{tabular}


Table 4. Correlation between maternal haemoglobin concentration and perinatal outcome.

\begin{tabular}{|c|c|c|c|c|c|}
\hline \multirow[t]{2}{*}{ Characteristics } & \multicolumn{2}{|c|}{ Haemoglobin $(\mathrm{g} / \mathrm{dL})$} & \multirow[t]{2}{*}{ Total } & \multirow[t]{2}{*}{$\mathrm{df}$} & \multirow{2}{*}{$\begin{array}{c}\text { Chi-Square }\left(\chi^{2}\right) \\
\quad(p-\text { value })\end{array}$} \\
\hline & Abnormal $(\leq 10.9)$ & Normal $(\geq 11)$ & & & \\
\hline \multicolumn{6}{|c|}{ Cord blood $\mathrm{Hb}(\mathrm{g} / \mathrm{dL})$} \\
\hline Abnormal $(\leq 11.9)$ & 29 & 11 & 40 & \multirow{3}{*}{1} & \multirow{3}{*}{$32.90^{\mathrm{OR}}(0.001)^{\star}$} \\
\hline Normal ( $\geq 12)$ & 24 & 91 & 115 & & \\
\hline Total & 53 & 102 & 155 & & \\
\hline \multicolumn{6}{|l|}{ Birth Weight (kg) } \\
\hline Underweight $(<2.5)$ & 8 & 11 & 19 & \multirow{4}{*}{2} & \multirow{4}{*}{$1.42(0.491)$} \\
\hline Normal (2.5-3.9) & 43 & 83 & 126 & & \\
\hline Macrosomic $(\geq 4)$ & 2 & 8 & 10 & & \\
\hline Total & 53 & 102 & 155 & & \\
\hline \multicolumn{6}{|l|}{ Apgar Scores (1 Min) } \\
\hline Abnormal $(\leq 6)$ & 12 & 11 & 23 & \multirow{3}{*}{1} & \multirow{3}{*}{$2.99(0.083)$} \\
\hline Normal (7 - 10) & 41 & 91 & 132 & & \\
\hline Total & 53 & 102 & 155 & & \\
\hline \multicolumn{6}{|c|}{ Apgar Scores (5 Mins) } \\
\hline Abnormal $(\leq 6)$ & 1 & 4 & 5 & \multirow{3}{*}{1} & \multirow{3}{*}{$0.04(0.841)$} \\
\hline Normal (7 - 10) & 52 & 98 & 150 & & \\
\hline Total & 53 & 102 & 155 & & \\
\hline \multicolumn{6}{|l|}{$\begin{array}{l}\text { Gestational Age } \\
\quad \text { (weeks) }\end{array}$} \\
\hline Preterm $(<37)$ & 8 & 12 & 20 & \multirow{2}{*}{1} & \multirow{2}{*}{$0.11(0.738)$} \\
\hline Term $(37-42)$ & 45 & 90 & 135 & & \\
\hline Total & 53 & 102 & 155 & & \\
\hline
\end{tabular}

${ }^{\star}$ Statistical significant $(\mathrm{p} \leq 0.05)$, Odds Ratio $(\mathrm{OR})=10.0(95 \% \mathrm{CI}=4.37-22.86)$.

\section{Discussion}

Anaemia in pregnancy is a major health problem especially in developing countries. It contributes significantly to maternal and perinatal morbidity and mortality [11]. In Nigeria, it is not uncommon to see patients with severe anaemia in pregnancy with no prior antenatal visits especially in sub-urban and rural areas. In many developing countries, malaria, helminthic infestations and poor nutrition make anaemia one of the most common medical problems in pregnancy [6]. The role played by malarial infestation in anaemia in pregnancy is well documented [6].

The prevalence of anaemia at delivery was $34.19 \%$. This was slightly lower than was previously reported from the University of Port Harcourt Teaching 
Hospital which was $47.9 \%$ [12]. The higher value obtained in the previous study may be because all the women were recruited at booking, before receiving routine haematinics and antimalarial chemoprophylaxis with suphadoxine-pyrimethamine usually given during the antenatal period. Also, women who developed anaemia at any point during pregnancy were treated accordingly. These may have influenced the haemoglobin concentration at delivery.

This study showed no significant difference in the mode of delivery and cord blood haemoglobin. This is in concert with the result from Ibadan [13]. Anaemia has been shown to be associated with preterm births and low birth weight babies by several researchers where they observed a U-shaped association between maternal haemoglobin concentration and birth weight [14]. Abnormally high haemoglobin concentrations may indicate poor plasma volume expansion which may be a risk for low birth weights [14]. Some studies have also reported low birth weights in anaemic women [15] [16].

However, the present study did not show any association as women with normal haemoglobin concentration also had both preterm births and low birth weight babies. Similar findings were obtained in Ibadan and Lagos where mild to moderate anaemia were not associated with preterm delivery and low birth weight babies [13]. This may be because only two women had severe anaemia.

The umbilical cord blood haemoglobin is an important haematological parameter in neonates. Haemoglobin ( $\mathrm{Hb})$ and haematocrit (Hct) values are often used in the diagnosis and follow-up of neonates with anaemia [17]. In this study, we considered $\mathrm{Hb}$ values $<12.0 \mathrm{~g} / \mathrm{dl}$ as anaemia and those $>12.0$ as normal. The mean cord blood $\mathrm{Hb}$ concentration was $12.92 \mathrm{~g} / \mathrm{dl}$. This is in keeping with findings by Adediran et al. in Lagos [18]. It was however lower than previously reported values from several other studies [19] [20] [21] [22]. This difference may be due to maternal parameters or geographical factors.

Few studies have shown a positive correlation between maternal haemoglobin and cord blood haemoglobin and also other perinatal outcomes whereas others did not show any correlation. In this study, we found that there was a linear relationship between the two parameters. It was observed as that as mean maternal haemoglobin decreases, there was a corresponding decrease in the cord haemoglobin and vice versa. This denotes that there is an impact of maternal anaemia on cord haemoglobin. This study also demonstrated that the cord haemoglobin is lower in a higher proportion of anaemic mothers. This suggests that placental iron transport mechanisms may not work as the anaemia becomes severe thereby leading to a fall in cord haemoglobin. This observation was similar to the study done in India and Babylon which also showed a linear relationship between maternal haemoglobin and cord haemoglobin of newborn [23] [24] [25].

However, a previous study reported that there was no association between cord haemoglobin and maternal haemoglobin levels except in cases of severe anaemia at birth thus leading to the conclusion that the fetus continues to extract iron efficiently from the mother regardless of her iron status [26]. 


\section{Conclusion}

Maternal anaemia affects the cord haemoglobin of neonates. There is a linear relationship between maternal haemoglobin and fetal haemoglobin. It is important to prevent maternal anaemia and maintain adequate iron stores during pregnancy with good nutrition, iron supplementation and adequate spacing between pregnancies especially in our sub-region. Routine cord blood haemoglobin may be done for early diagnosis of neonatal anemia and appropriate intervention instituted.

\section{Limitation}

The maternal haemoglobin concentration was not determined in the first and second trimesters and compared with that in labour. It is likely that mothers who were anaemic in labour had poor iron intake during pregnancy, which may have led to decreased cord haemoglobin concentration. Also, the iron status of the mothers and their newborns were not determined. Further studies are needed to determine the relation of iron stores of the mother to the fetal iron and ferritin levels.

\section{Acknowledgements}

The authors acknowledge Dr. Atochi Woruka and Dr. Appolus Isaac for their immense contribution in collating the data.

\section{Consent}

All authors declare that informed written consent was obtained from the patient for this study.

\section{Conflicts of Interest}

The authors declare no conflicts of interest regarding the publication of this paper.

\section{References}

[1] Benoist, B., Mclean, E., Egli, I. and Cogswell, M. (2008) Worldwide Prevalence of Anaemia 1993-2005. WHO Global Database on Anaemia. World Health Organization, Geneva.

[2] World Health Organization (2015) The Global Prevalence of Anemia in 2011. WHO, Geneva.

[3] Harrison, K.A. (2001) Anaemia in Pregnancy. In: Lawson, J.B., Harrison, K.A. and Bergstrom, S., Eds., Maternity Care in Developing Countries, RCOG Press, London, 112-128.

[4] Agan, T., Ekabua, J.E., Udoh, A.E., Ekanem, E.I., Efiok, E.E. and Mgbekem, M.A. (2010) Prevalence of Anemia in Women with Asymptomatic Malaria Parasitemia at First Antenatal Care Visit at the University of Calabar Teaching Hospital, Calabar, Nigeria. International Journal of Women's Health, 2, 229-233. https://doi.org/10.2147/IJWH.S11887

[5] Haggaz, A.D., Radi, E.A. and Adam, I. (2010) Anaemia and Low Birth Weight in Western Sudan. Transactions of the Royal Society of Tropical Medicine and Hy- 
giene, 104, 234-236. https://doi.org/10.1016/j.trstmh.2009.07.013

[6] Breymann, C., Bian, X.M., Blanco-Capito, L.R., Chong, C., Mahmud, G. and Rehman, R. (2011) Expert Recommendations for the Diagnosis and Treatment of Iron-Deficiency Anemia during Pregnancy and the Postpartum Period in the Asia-Pacific Region. Journal of Perinatal Medicine, 39, 113-121. https://doi.org/10.1515/jpm.2010.132

[7] Say, L., Chou, D., Gemmill, A., Tunçalp, O., Moller, A., Daniels, J., et al. (2014) Global Causes of Maternal Death: A WHO Systematic Review. The Lancet Global Health, 2, e323-e333. https://doi.org/10.1016/S2214-109X(14)70227-X

[8] Scholl, T.O. (2011) Maternal Iron Status: Relation to Fetal Growth, Length of Gestation, and Iron Endowment of the Neonate. Nutrition Reviews, 69, S23-S29.

https://doi.org/10.1111/j.1753-4887.2011.00429.x

[9] Shao, J., Lou, J., Rao, R., Michael, K., Georgieff, K., Kaciroti, N., et al. (2012) Maternal Serum Ferritin Concentration Is Positively Associated with Newborn Iron Stores in Women with Low Ferritin Status in Late Pregnancy. The Journal of Nutrition, 142, 2004-2009. https://doi.org/10.3945/jn.112.162362

[10] Elgari, M.M. and Waggiallah, H.A. (2013) Assessment of Hematological Parameters of Neonatal Cord Blood in Anemic and Non-Anemic Mothers. Journal of Clinical \& Experimental Research, 1, 22-25. https://doi.org/10.5455/jcer.201321

[11] Ekem, I. and Obed, S.A. (2015) Anaemia in Pregnancy. In: Kwawukume, E.Y., Ekele, B.A., Danso, K.A. and Emuveyan, E.E., Eds., Comprehensive Obstetrics in the Tropics, Assemblies of God Literature Centre Limited, Accra, 332-337.

[12] Ogu, R.N. and Ikimalo, J.I. (2018) The Impact of Haematinics Supplementation during Pregnancy on Maternal Anemia and Perinatal Outcome among Parturients in Southern Nigeria-A Prospective Study. Journal of Gynecology and Women's Health, 9, 555758. https://doi.org/10.19080/JGWH.2018.09.555758

[13] Awonuga, D.O., Odukogbe, A.A., Olayemi, O. and Adeniji, A.O. (2012) Anaemia in Pregnancy: Maternal and Perinatal Outcome in Ibadan, South Western Nigeria. Tropical Journal of Obstetrics and Gynaecology, 29, 7-14.

[14] Moghaddam, T.F. and Barjasteh, S. (2015) Maternal Haemoglobin Level during Pregnancy and Their Association with Birth Weight of Neonates. Iranian Journal of Pediatric Hematology and Oncology, 5, 211-217.

[15] Ahmad, M.O., Kalsoom, U., Sughra, U., Hadi, U. and Imran, M. (2011) Effect of Maternal Anaemia on Birth Weight. Journal of Ayub Medical College Abbottabad, 23, 77-79.

[16] Rahmati, S., Delpishe, A., Azami, M., Ahmadi, M.R.H. and Sayehmiri, K. (2017) Maternal Anemia during Pregnancy and Infant Low Birth Weight: A Systematic Review and Meta-Analysis. The International Journal of Reproductive BioMedicine, 15, 125-134. https://doi.org/10.29252/ijrm.15.3.125

[17] Paiva, A.A., Rondo, P.H., Pagliusi, R.A., Latorre, M.R., Cardoso, M.A. and Gondim, S.S. (2007) Relationship between the Iron Status of Pregnant Women and Their Newborns. Revista de Saúde Pública, 41, 321-327. https://doi.org/10.1590/S0034-89102007000300001

[18] Adediran, A., Gbadegesin, A., Adeyemo, T.A., Akinbami, A., Osunkalu, V., Ogbenna, A., et al. (2013) Cord Blood Haemoglobin and Ferritin Concentrations in Newborns of Anaemic and Non-Anaemic Mothers in Lagos, Nigeria. Nigerian Medical Journal, 54, 22-26. https://doi.org/10.4103/0300-1652.108889

[19] Nneli, R.O., Amadi, S.C.A. and Nwafia, W.C. (2011) Certain Red Blood Cell Indices of Maternal and Umbilical Cord Blood in Owerri, Nigeria: A Preliminary Report. Annals of Medical and Health Science Research, 1, 1-8. 
[20] Abdulqadir, I., Ahmed, S.G., Kuliya, A.G., Tukur, J., Yusuf, A.A. and Ndakotsu, M.A. (2017) The Haematological Parameters of Normal Pregnant Women and Cord Blood of Their Newborns in Aminu Kano Teaching Hospital, Kano Nigeria. Sub-Saharan African Journal of Medicine, 4, 75-78. https://doi.org/10.4103/ssajm.ssajm_16_17

[21] Timilsina, S., Karki, S., Gautam, A., Bhusal, P., Paudel, G. and Sharma, D. (2018) Correlation between Maternal and Umbilical Cord Blood in Pregnant Women of Pokhara Valley: A Cross Sectional Study. BMC Pregnancy and Childbirth, 18, Article No. 70. https://doi.org/10.1186/s12884-018-1697-1

[22] Qaisar, D.H., Sandila, M.P., Omair, A. and Ghori, G.M. (2013) Correlation of Routine Haematological Parameters between Maternal Blood and the Cord Blood of Healthy Newborns in Selected Hospitals of Karachi. Journal of the College of Physicians and Surgeons-Pakistan, 23, 128-131.

[23] Dhanasekaran, R., Sumitha, A. and Suguna (2019) Impact of Maternal Anaemia on Cord Blood Haemoglobin. International Journal of Contemporary Pediatrics, 6, 1235-1238. https://doi.org/10.18203/2349-3291.ijcp20192018

[24] Debbarma, R., Debbarma, B. and Devi, M.A. (2015) Effect of Maternal Anaemia on Cord Haemoglobin and Birth Weight of Newborn. IOSR Journal of Dental and Medical Sciences, 14, 19-21.

[25] Khan, A. and Agarwal, D. (2018) Effect of Maternal Anaemia on Cord Blood Haemoglobin. International Journal of Clinical Obstetrics and Gynaecology, 2, 15-17.

[26] Najeeba, C.M., Prabhu, A.S. and Saldanha, P.R.M. (2015) Maternal Anaemia and Its Effect on Cord Blood Haemoglobin and New-Born Birthweight. IOSR Journal of Dental and Medical Sciences, 14, 30-32. 